\title{
Methods of Encapsulation of Biomacromolecules and Living Cells. Prospects of Using Metal-Organic Frameworks
}

\author{
A. V. Sokolov ${ }^{a}$, L. V. Limareva ${ }^{a}$, P. V. Iliasov ${ }^{a} *$, O. V. Gribkova ${ }^{a}$, and A. S. Sustretov ${ }^{a}$ \\ ${ }^{a}$ Institute of Experimental Medicine and Biotechnologies, Samara State Medical University, \\ Ministry of Health of the Russian Federation, Samara, 443099 Russia \\ *e-mail:p.v.ilyasov@samsmu.ru
}

Received December 25, 2020; revised December 29, 2020; accepted December 31, 2020

\begin{abstract}
The review discusses different methods of encapsulation and biomineralization of macromolecules and living cells. Main advantages and disadvantages of most commonly used carriers, matrices, and materials for immobilization of proteins, enzymes, nucleic acids, and living cells are briefly surveyed. Examples of delivery vehicles for multifunctional encapsulation of protein-like substances are presented. Particular attention is paid to prospects of using metal-organic frameworks in medicine and biotechnology.
\end{abstract}

Keywords: polymer nanoparticles, inorganic nanoparticles, metal-organic frameworks, immobilization, encapsulation, biomineralization

DOI: $10.1134 / \mathrm{S} 1070428021040011$

1. Introduction 491

2. Encapsulation of Proteins 491

3. Encapsulation of Nucleic Acids 494

4. Encapsulation of Cells and Microorganisms 495

5. Multifunctional Encapsulation 498

6. Conclusions 498

\section{INTRODUCTION}

Immobilization of biomacromolecules and cells underlies the key approach to the design of new biomaterials, catalysts, and medicines and development of bioprocesses. There are numerous immobilization methods, the most promising of which for biomedical purposes are encapsulation and biomineralization, since they provide protection from environmental factors, stabilization, and controlled release of the content.

Up to now, a large number of various carriers, matrices, and materials for encapsulation and biomineralization of biological components have been proposed. Among them, the most widespread are gel materials, micellar, vesicular, and membrane systems, organic and inorganic polymeric structures, as well as metalorganic frameworks (MOFs) (Fig. 1). Each type of carriers features structural and functional peculiarities, advantages, and disadvantages, and their choice in each particular case depends on the objectives of a study, immobilized component, and researcher's preferences.

\section{ENCAPSULATION OF PROTEINS}

Nowadays, protein-based biologically active compounds and drugs, such as hormones, antioxidants, enzymes, enzyme inhibitors, vaccines, antitumor agents, etc., have gained wide application in medicine, food industry, and biotechnology. On the other hand, their use is associated with some limitations, the main of which are related to high sensitivity of proteins and medicines to denaturation, aggregation, or hydrolysis in the gastrointestinal tract (GIT), undesirable interactions of components of a medicine with each other or with other medicines, poor absorption of proteins in the GIT, hydrophobicity, instability and degradation on storage, toxicity, and immunogenicity of foreign protein components [1-5]. One of the approaches to overcome these limitations is based on encapsulation of proteins using appropriate carriers [1, 6-11]. For example, colloidal delivery systems suitable for encapsulation of proteins include microemulsions, emulsions, micelles, solid lipid nanoparticles, liposomes, polymersomes, sol-gels, and hydrogels $[3,12,13]$ 


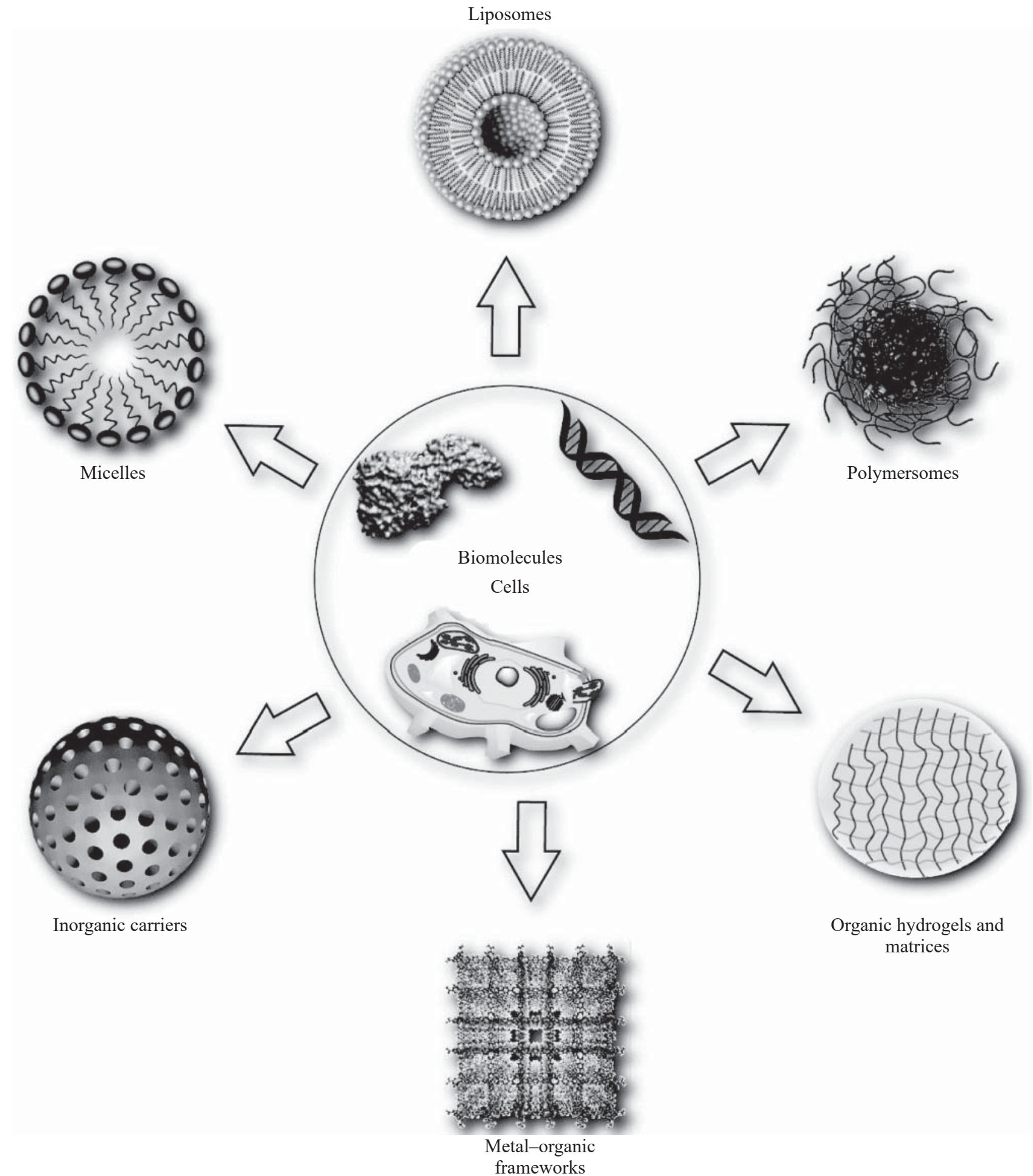

Fig. 1. Carriers and matrices for encapsulation and biomineralization of biological components.

(Fig. 1). Inorganic mesoporous particles (silicon dioxide nanoparticles, hydroxyapatite, calcium phosphates, etc.) and polymer-based particles, including those of protein nature, have been extensively used [14-19]. In particular, insulin was encapsulated in chitosan and pectin nano- and microparticles, which made it possible to avoid hormone injection and develop dosage forms for oral administration [20]. Liposomal forms of drugs and antigens are also widely used for these purposes, which makes it possible to overcome biocompatibility 
problems and provides targeted delivery and protection from undesirable immune response. Liposomes are used in the design of vaccines to ensure induction of antibodies and T-cell reactions to associated antigen subunits [8].

On the other hand, the described technologies for encapsulation of biologically active protein-like substances are not free from some drawbacks which should be taken into account in their practical implementation. These include the need to standardize matrices with respect to size, shape, and particle charge, especially when controlled release of an encapsulated substance is necessary. In particular, owing to the small pore size of inorganic carriers, trapping of molecules of only a certain size is possible [21, 22]. In some cases, there is poor reproducibility of microspheres, as well as deactivation of a protein during preparation, storage, and release from the created particles. In order to avoid toxicity and undesirable interactions between the components of the resulting preparation, careful selection of ingredients of the encapsulating systems is required. The main factors limiting successful application of liposomes in practice are potential cytotoxic effects of liposomes, toxicity of charged liposomes [23, 24], their leakage, possible presence of trace amounts of organic solvents (ethanol, ether) in the final preparation [25], poor batch-to-batch reproducibility, low sorption of the drug payload [26], lack of effective sterilization methods [27-29], and stability [30-32] and scaling problems. Other disadvantages of using vesicular systems, including liposomes, as well as solid lipid particles, are their high cost, laborious production, susceptibility to degradation during storage, and the need to control aggregation of colloidal particles. Until now, problems associated with limited drug load volume of micellar systems and stability of formulations encapsulated therein have not been resolved [2, 5, 10, 26, 33].

In many cases, the above problems can be solved by using encapsulation matrices based on metal-organic frameworks (MOFs). They are characterized by structural rigidity which favors protein fixation and hence prevents protein denaturation or degradation. It was demonstrated [34] that insulin encapsulated in NU-1000 zirconium-based mesoporous MOF remains stable toward gastric juice and is not destroyed by pepsin, but it degrades in a phosphate buffer that mimics physiological conditions in tissues, which makes it possible to control its release. The composite material remains unchanged on heating above $50^{\circ} \mathrm{C}$, so that the insulin structure is maintained intact. The obtained results can be used to develop alternatives to insulin pumps, as well as new formulations for the delivery of insulin.

Biomimetic methods have been developed for encapsulation of proteins in MOFs to deliver one or several proteins to cellular structures with the goal of finding new approaches to the treatment of tumors. The obtained hybrid materials conserved protein molecules on storage for several months. Chu et al. [35] described a biomimetic mineralization method for the synthesis of protein-encapsulating MOF nanoparticles (NPs) which preserved protein activity and protected proteins from enzyme-mediated degradation. Moreover, the developed platform was demonstrated to enable easy encapsulation of multiple proteins in single MOF NPs for their efficient co-delivery.

Encapsulation of hemoglobin in zeolite-like ZIF-8 MOF significantly enhanced its stability while maintaining the ability of encapsulated hemoglobin to transport oxygen in vivo with an efficiency of $80-90 \%$ relative to native hemoglobin. Experiments in mice showed that the resulting composite is not immunogenic; its surface charge is close to zero, which prevents protein adsorption on the surface. The composite nanoparticles are absorbed by macrophages approximately 3 times slower, and they do not change the activity of blood enzymes. The elimination half-life is $14 \mathrm{~h}$, and the cytotoxicity of the composite is lower than that of bare ZIF-8 NPs. The composite decomposes at pH 5.0 in cell lysosomes, which reduces the risk of accumulation of nanoparticles in vivo. Administration of the composite significantly extended the survival time of mice subjected to hemorrhagic shock [36].

Biocatalysts, including enzymes, play an important role in medical and food industries and biotechnology $[37,38]$. For biotechnological applications, of particular significance are increased stability and efficiency of enzymes and the possibility of their repeated use in biocatalysis, biotransformations, preparation of various products, etc. These goals can be achieved through the use of various carriers, such as dendrimers and dendrisomes, micelles, liposomes, polymer vesicles (polymersomes), emulsions, inorganic mesoporous nanoparticles of silicon dioxide, hydroxyapatite, etc. [21, 22, 39-41], as well as MOFs [42]. Encapsulation of enzymes as a version of their immobilization makes it possible to protect them from the action of aggressive media, maintain catalytic activity, deliver them to the body for therapeutic purposes, reduce the risk of allergic reactions, and combine biologically active sub- 
stances into multienzyme complexes (nanoreactors) [40, 43-47].

In particular, a high antitumor effect of encapsulated L-asparaginase has been demonstrated. Encapsulation increased the proteolytic stability of the enzyme and weakened its recognition by antibodies, which reduced the potential frequency of drug administration and the risk of inducing immune response [40].

Caruso et al. [44] proposed a method for encapsulation of proteins via sequential multilayer coating of protein crystals with polymers using catalase as an example. Methodological simplicity of this approach and the stability of the resulting coating to the action of proteases were demonstrated.

Incorporation of acetylcholinesterase and some other enzymes into liposomes made it possible to stabilize them and protect from the action of proteases [45]. The preparation and use of liposomes for the encapsulation of various enzymes in the food industry were considered in [37]. Modern technologies provide a combination of several biologically active substances on a single carrier to produce multienzyme complexes. Van Hest et al. [47] described polymersomes with hierarchical immobilization of three enzymes (glucose oxidase, lipase, and horseradish peroxidase) as nanoreactors.

Limitations and problems related to encapsulation of enzymes are determined by the structure of the carriers; accordingly, these limitations can often be overcome by modification of the carrier structure. For example, the ability of polymersomes to retain and protect its load was enhanced through cross-linking of their membranes with special compounds and hydrophobic primary amines $[41,48]$. Various lipids and proteins were introduced into the layers of liposomes to increase their stability [45]. In addition, a common problem in the encapsulation of enzymes in polymer capsules is unwanted desorption of biologically active substances during storage and delivery [49]. An alternative method for stabilizing enzymes while maintaining their catalytic properties is their encapsulation in MOFs (Fig. 2a).

It was shown [50] that MIL-100(Fe) MOF can be used to encapsulate pancreatic lipase as a reusable catalyst. The catalyst retained its activity over 8 cycles and was insensitive to acidity of the medium in the $\mathrm{pH}$ range 3.0-9.0; the catalytic activity did not change up to $70^{\circ} \mathrm{C}$. The high capacity of semicrystalline MIL-100(Fe) with respect to lipase and lactase was demonstrated, and no more than $10 \%$ of enzyme molecules was lost during the technological process [51].
Zeolite-like imidazolate MOFs (ZIF) (unlike other MOFs, they can be synthesized under physiological conditions) were successfully used to encapsulate unstable enzymes such as peroxidase, urease, alcohol dehydrogenase, and glucose oxidase [52-54]. The resulting ZIF-enzyme showed a high resistance to denaturing solvents like DMSO, DMF, and alcohols [55]. An interesting example is encapsulation of enzymes in porous hydrogen-bonded organic frameworks (HOF) [56] which have no cytotoxic properties and possess large pore dimensions. However, while designing encapsulated enzymes of a similar structure, it is necessary to take into account that in some cases transition metal-based MOFs can exhibit a catalytic effect $[57,58]$.

\section{ENCAPSULATION OF NUCLEIC ACIDS}

Vector construction is a critical step in genetic engineering and therapy. Viral, plasmid, and other constructs based on nucleotide sequences are usually used as genetic vectors. Such vectors can be specific and/or nonspecific for certain target cells; they are capable of being inserted into the genome, providing constitutive or inducible expression of a transgene that replaces or compensates for defective or undesirable host genes, and carry or not carry replicative mechanisms, depending on their function. Recently, there has been growing interest in RNA interference technologies, as well as in genome editing methods based on CRISPR/Cas systems and their analogues, which open broad prospects for gene therapy. A common drawback of such structures is their immunogenicity, as well as a number of limitations in the targeted delivery and transformation of target cells in vivo, which are associated, in particular, with the need to protect vectors from the immune system and nucleases. One way to overcome these limitations is encapsulation of transgenes into various carriers with or without vectors; in the latter case, vector functions, i.e., transgene delivery into the cell and ensuring its functioning therein, are performed by the carrier (Fig. 2b).

Polymer matrices and micellar structures are generally not used for encapsulation of nucleic acids due to difficulties in the transformation of such vectors. Recent publications reported the use of MOFs as abiogenic analogs of genetic vectors due to the possibility of their endocytosis. The presence of an extended hydrogen bond system in the structure of nucleic acids and comparable pore diameters in MOFs provides the possibility for the encapsulation process to involve 
(a)

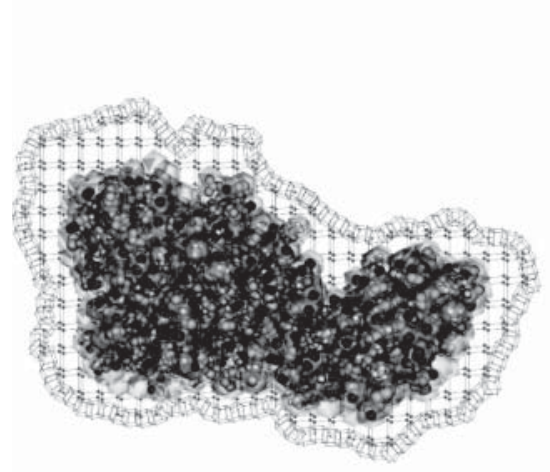

(b)

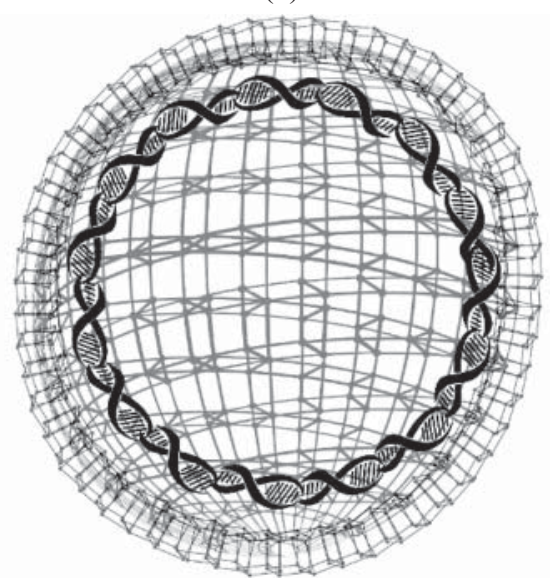

(c)

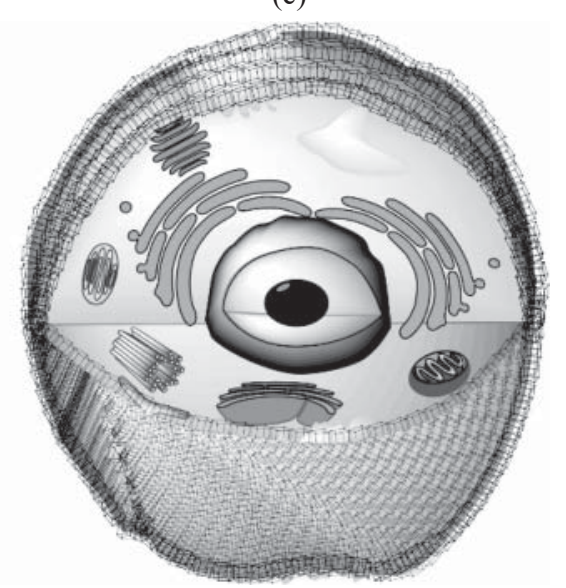

Fig. 2. Encapsulation into a MOF crystal of (a) enzyme molecule, (b) plasmid DNA, and (c) intact cell.

both biomineralization and reversible adsorption of nucleic acids within MOF pores [53, 59]. In the latter case, the release and uptake of nucleic acids can be controlled by changing properties of the carrier without destroying it, which makes it possible to implement a controlled platform for genetic manipulation. This approach was demonstrated [60] using nickel-based isoreticular MOF (Ni-IRMOF-74), where precisely tuned pore diameter was selected for reversible interaction with single-stranded DNA, and successful transfection of primary mouse immune cells $\left(\mathrm{CD} 4^{+} \mathrm{T}\right.$-cells) and human immune cells (THP-1) was performed with an efficiency of 92 and 30\%, respectively. Another MOF, namely ZIF-8, was used as a transfection vehicle for progenitor cells from the Langerhans islets [61]. The low toxicity and ease of use of such a carrier was demonstrated. Nanocomposites based on zirconium MOF NU-1000 and small interfering RNA [62] were used for gene knockdown in the HEK293 cell line.

In addition to interfering nucleic acids and other oligonucleotides, plasmid DNA encoding the production of the fluorescent protein plGFP was encapsulated in ZIF-8 [63], and successful transfection of the PC-3 cell culture with the resulting material was performed. It was noted that due to the slow release and expression of foreign DNA, as well as stabilizing properties of the MOF, the cytotoxicity of this transfection method was significantly lower than that of analogs.

\section{ENCAPSULATION OF CELLS AND MICROORGANISMS}

Encapsulation and biomineralization of cells are widely used in various fields of biotechnology and provide a number of advantages, including, apart from reduced consumption of the biomaterial, its protection from aggressive environment, controlled release, and repeated use of immobilized agents, the formation of spatial structures that mimic body tissues, biofilms, etc. The use of some gels and polymers makes it possible to optimize the state of cells and thereby contribute to their stability or modulate their activity [64]. All this ensures the efficiency of using immobilized biocomponents in cell cultivation [65], biofuel production [66], biotransformation of various compounds, and other biotechnological processes associated with biocatalysis, in particular during environmental remediation [67] and therapeutic use (e.g., for wound healing $[68,69])$, as well as for bioanalytical purposes (e.g., as components of biosensor receptors).

A promising approach is based on the possibility of obtaining structures similar to biological membranes, organs, and tissues [70] with the goal of using them as implants or in tissue engineering [71-73]. The method and the carrier are selected on the basis of the stability of biomaterial and its activity, including diffusion properties of the carrier. In most cases, cells are immobilized by adsorption or inclusion in gel and polymer matrices. Covalent binding by difunctional agents is used relatively rarely due to toxicity of this method for cells [74, 75]. Various membranes [76-82], filter paper [83, 84], carbon materials [85], etc., are used as carriers for adsorption. One of the main advantages of the adsorption method is its technological simplicity. Furthermore, adsorption is a "soft" immobilization method, which usually exerts minimum damage to cells [86]. The stability of indications for the use of sorbed cells and enzymes is usually quite high. Functioning of enzymes and cells without loss of 
activity for several weeks or even months was noted in a number of publications [80, 87, 88]. All these factors make adsorption one of the most preferred techniques. Immobilization of cells within MOFs can also be achieved through adsorption, covalent binding on the MOF surface, incorporation into pores of the carrier, coprecipitation, and in situ synthesis [89].

Gel encapsulation is used in biotechnology approximately as often as adsorption, and it is practically indispensable when microorganisms are poorly retained on the carrier. In the general case, encapsulation of cells in gel or polymer matrices is more advantageous than adsorption due to higher stability of the cells [90]. In addition, some polysaccharide gels (e.g., agar gels) reduce the toxic effect of aromatic compounds on cells [91], which is an important criterion for their use. Agar [92], calcium alginate [74, 93-95], carrageenan [96], gelatin, and collagen gels [97-99] and polyvinyl alcohol (PVA) [100-102] are widely used. Although polymerization of these carriers is performed under harsh conditions (high temperature or ionic strength of the medium or UV irradiation), they provide high stability of the biomaterial and reproducibility of its operation. Polyacrylamide gel is used quite often [103] despite its toxicity. Other carriers such as PVA-based cryogels [104, 105], ENT/ENTP photocrosslinked polymers (polymer mixture based on polyethylene or polypropylene glycol, hydroxyethyl acrylate, and isophorone diisocyanate, which is polymerized under near UV irradiation) or modified PVA [106], granules and films based on polyvinyl chloride [107], hydrogels based on chitosan [108-110], polycarbamoyl sulfonate $[111,112]$, and polyurethane $[113,114]$, peptide polymers [115], biotin-avidin linkers [116-118], solgel matrices based on aluminum oxide [119] or composite polymers [120-123], as well as electropolymerizable polyaniline films [124-127] and other compounds [128, 129], and nanostructured materials (including carbon nanotubes and metal nanoparticles) [130-137] should also be noted. A common disadvantage of encapsulation in gels and polymers is diffusion restrictions imposed by the carrier nature, which in some cases appreciably reduce the rate of biocatalysis and the activity of biocomponents.

The use of MOFs as encapsulating matrices leads to the formation of crystalline extracellular structures similar to those arising from mineralization with inorganic salts. However, in this case, the extracellular structure has an ordered pore structure and selective permeability to ions and low-molecular-weight com- pounds, which has a specific effect on the cell life cycle and functioning (Fig. 2c).

Liang et al. [138] showed that ZIF-8 (zeolitic imidazolate framework) can be crystallized on the surface of Saccharomyces cerevisiae and Micrococcus luteus to form a protective coating on the respective cell walls, which provided almost $90 \%$ survival in the presence of lyticase, as well as under the action of antibiotics. This demonstrated homogeneity of the coating with respect to both biomacromolecules and relatively low-molecular-weight compounds. In addition, the biomineralization was found to induce cell hibernation which can be controlled by introducing a compound that lyses the exoskeleton (e.g., EDTA). When $\beta$-galactosidase, an enzyme which is untypical of $S$. cerevisiae and capable of decomposing lactose into natural nutrients, was immobilized on the surface of the exoskeleton, the nutrients were assimilated through the pores of ZIF-8, leading to enhanced survival and adaptation to oligotrophic conditions [139].

Biomineralization of the anaerobic bacterium Moorella thermoacetica with a monomolecular layer of MOF based on zirconium and 1,3,5-tris(4-carboxyphenyl)benzene significantly increased its survival under aerobic conditions. In this case, cytoprotection was achieved due not only to isolation of cells from the environment but also to the catalytic action of MOF which traps reactive oxygen species at unsaturated coordination sites of zirconium oxo clusters. An interesting fact was the ability of bacteria wrapped by MOF monolayer to reproduction, which was provided by the elasticity of the cytoprotective layer that does not prevent cell division [140].

Biomineralization of cellular structures can have functions opposite to protective ones. Thus, effective photodynamic ablation of bacterial biofilms was performed using composite materials based on porphyrincontaining MOFs capable of generating singlet oxygen [141], which can find application in both medicine and biotechnology.

Apart from cellular structures, fragments of cells and viral particles used as vaccines can be subjected to biomineralization to increase their stability and regulate immunological reactivity through gradual release of antigens [142-144]. Bacterial cell membranes can be utilized as a scaffold for MOF to form microcapsules with selective release of their content [145]. In some cases, MOFs can have a separate protective function, e.g., that similar to antifreeze proteins which prevent ice crystal growth; this can be used for cryopreservation of erythrocytes [36]. 
METHODS OF ENCAPSULATION OF BIOMACROMOLECULES AND LIVING CELLS.

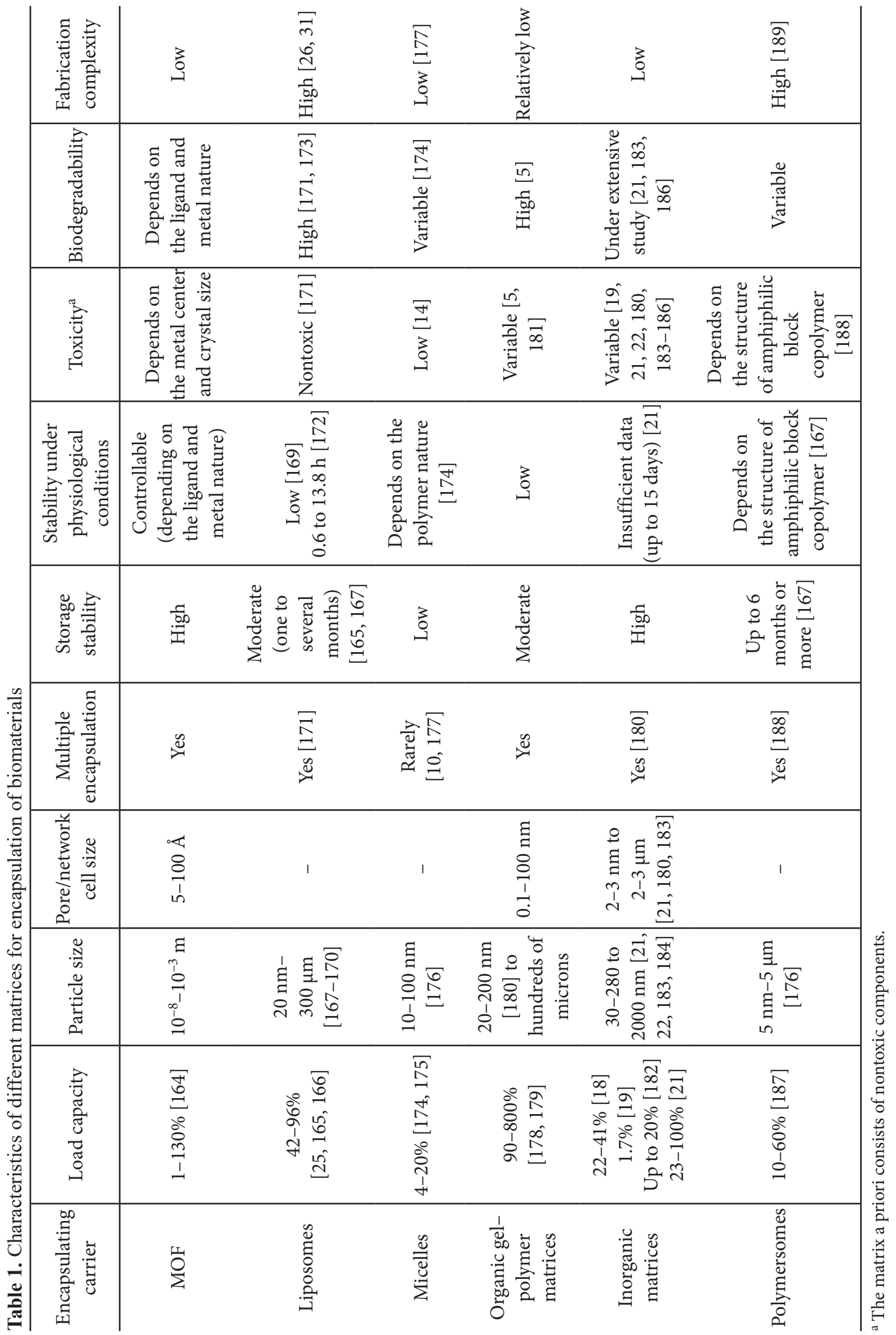




\section{MULTIFUNCTIONAL ENCAPSULATION}

The development of highly effective drugs for polymodal therapy of oncological and infectious diseases requires simultaneous delivery or sequential release of biomolecules. These problems can be solved through automated formation of complex structures with high spatial resolution, containing immobilized cells and enzymes. Inkjet printing was used [146] to create highdensity matrices with encapsulated bacterial cells. An inkjet printer was also employed to immobilize cells conjugated to single-stranded DNA on a surface modified with complementary DNA [147]. A similar approach was utilized previously for enzymes, DNA, and antibodies [148-151]; however, its application to intact cells is a rare case. Furthermore, the use of scanning probe lithography to obtain carriers based on microcellular structures containing microbial cells has been described [152]. Such matrices are in demand in the fields of cell biology, immunology, and drug development. As well as organic structures, MOFs can be used to encapsulate dissimilar molecules. For example, simultaneous immobilization of nickel-palladium nanoparticles and glucose oxidase in ZIF-8 led to the formation of self-organized crystal structures with enzymatic properties, and glucose sensors were developed on the basis of such structures [153]. When nickel-palladium nanoparticles were replaced by $\mathrm{Fe}_{3} \mathrm{O}_{4}$ nanoparticles, the composite became magnetically susceptible [154], which can be used to create controlled biocatalysts.

Metal-organic frameworks for simultaneous encapsulation of several enzymes for biomedical purposes have been designed and synthesized [155]. Zirconiumcontaining MOF UiO-66 was shown [156] to simultaneously absorb glucose oxidase and peroxidase. The resulting biocatalyst displayed a higher activity than that of the free enzymes; however, the carrier lost enzymes within a few days due to the equilibrium nature of adsorption. Enzymes encapsulated in MOF were used to catalyze multienzyme cascade reactions; in particular, carbon dioxide was converted to formate anion using a layered structure consisting of MIL101(Cr) and HKUST-1 with immobilized carbonic anhydrase and formate and glutamate dehydrogenases [157]. This study provided an important evidence of the possibility of developing biomimetic methods for removal of greenhouse gases.

The presence of catalytically active metal centers in the MOF structure, originating from local defects and disturbances in the crystal lattice, in combination with the molecular recognition effect determined by the strictly ordered shape and interior of the pores, as well as with a high surface area, in some cases endows the carrier with a catalytic activity similar to the activity of native enzymes [158]. At present, structures with catalase [159], peroxidase [160,161], and laccase [162] activities have been characterized. In future, such MOFs can be used as analogs of enzyme markers for the development of enzyme immunoassay and immunochromatographic assay systems.

The possibility of encapsulation of DNA enzymes together with low-molecular-weight compounds was demonstrated by the synthesis of ZIF-8 nanoparticles containing DNA molecules and a photosensitizer [163]. It was found that the resulting nanomaterial effectively penetrates without degradation tumor cell membranes in $\mathrm{BALB} / \mathrm{c}$ female nude mice bearing MCF-7 tumors and allows simultaneous photodynamic and gene therapy of cancer.

Brief characteristics, advantages, and disadvantages of various carriers for encapsulation of biocomponents are collected in Table 1.

The above considered aspects make encapsulation and biomineralization promising for the development of biomaterials with controlled parameters. Such materials can find diverse applications in various fields of biotechnology and medicine.

\section{CONCLUSIONS}

Encapsulation is one of the most common methods for stabilizing biomacromolecules and living cells. Due to the wide field of application and numerous medical and biotechnological problems, almost the entire range of biocompatible or nontoxic materials capable of forming structured objects have been used for encapsulation. The general requirement for encapsulating agents is the stability of the content to effects of the external environment, invariability of their structure and composition over time, high load capacity, and biodegradability. However, in most cases it is difficult to meet all these requirements simultaneously, since organic colloidal structures are thermodynamically unstable, while inorganic matrices are difficult to decompose under physiological conditions or their capacity is low. In this respect, MOFs are most appropriate as encapsulating agents. These carriers are characterized by high capacity, resistance to drying and denaturing agents, as well as by the possibility of being imparted with controlled properties, flexibility of design, and a wide variety of potentially realizable 
topologies. The presence of an ordered pore system of pores that are permeable to certain molecules, thermal stability, and the possibility of selective degradation of MOFs due to the difference in physiological conditions in the intra- and extracellular space make it possible to implement new biotechnological processes and create medical composite materials with desired properties. Thus, the use of MOFs for encapsulation and mineralization of biomacromolecules and living cells is a dynamically developing area with undoubted prospects for practical application, including drug delivery, design of biocatalysts for biotechnological purposes, and preparation of cellular structures for tissue regeneration. Nowadays, the use of MOFs is limited by a poor diversity of biocompatible organic ligands and toxicity of metals and by the lack of information on the potential use of previously unused metals and ligands. However, a significant increase in the number of studies of the properties of MOFs and a short period of time elapsed from their discovery give reason to believe that new therapeutic agents and methods, dosage forms, and highly effective biocatalysts will be developed in the nearest future.

\section{CONFLICT OF INTEREST}

The authors declare no conflict of interest.

\section{REFERENCES}

1. Ye, C. and Chi, H., Mater. Sci. Eng., C, 2018, vol. 83, p. 233. https://doi.org/10.1016/j.msec.2017.10.003

2. Perry, S.L. and McClements, D.J., Molecules, 2020, vol. 25, p. 1161.

https://doi.org/10.3390/molecules25051161

3. Pérez-Luna, V.H. and González-Reynoso, O., Gels, 2018, vol. 4, p. 61. https://doi.org/10.3390/gels4030061

4. Henriksen, P.A., Heart, 2018, vol. 104, p. 971. https://doi.org/10.1136/heartjnl-2017-312103

5. Sikder, S., Gote, V., Alshamrani, M., Sicotte, J., and Pal, D., Expert Opin. Drug Delivery, 2019, vol. 16, p. 1113. https://doi.org/10.1080/17425247.2019.1662785

6. McClements, D.J., Adv. Colloid Interface Sci., 2018, vol. 253 , p. 1. https://doi.org/10.1016/j.cis.2018.02.002

7. Richard-Carpentier, G. and DiNardo, C.D., Hematology, 2019, vol. 2019, p. 548. https://doi.org/10.1182/hematology.2019000059

8. Watson, D.S., Endsley, A.N., and Huang, L., Vaccine, 2012, vol. 30, p. 2256.

https://doi.org/10.1016/j.vaccine.2012.01.070
9. Schwendener, R.A., Ther. Adv. Vaccines Immunother., 2014, vol. 2, p. 159.

https://doi.org/10.1177/2051013614541440

10. Zhang, Y., Huang, Y., and Li, S., AAPS PharmSciTech, 2014 , vol. 15 , p. 862.

https://doi.org/10.1208/s12249-014-0113-z

11. Gupta, S., Kaushal, A., Kumar, A., and Kumar, D., Int. J. Biol. Macromol., 2017, vol. 105, p. 905. https://doi.org/10.1016/j.ijbiomac.2017.07.126

12. Wang, X., Ahmed, N.B., Alvarez, G.S., Tuttolomondo, M.V., Helary, C., Desimone, M.F., and Coradin, T., Curr. Top. Med. Chem., 2015, vol. 15, p. 223. https://doi.org/10.2174/1568026614666141229112734

13. Venditti, I., J. King Saud Univ. Sci., 2019, vol. 31, p. 398. https://doi.org/10.1016/j.jksus.2017.10.004

14. Akash, M.S.H., Rehman, K., and Chen, S., Pharm. Dev. Technol., 2016, vol. 21, p. 367. https://doi.org/10.3109/10837450.2014.999785

15. Liu, H., Cui, Y., Li, P., Zhou, Y., Chen, Y., Tang, Y., and Lu, T., Anal. Chim. Acta, 2013, vol. 776, p. 24. https://doi.org/10.1016/j.aca.2013.03.040

16. Tarhini, M., Greige-Gerges, H., and Elaissari, A., Int. J. Pharm., 2017, vol. 522, p. 172. https://doi.org/10.1016/j.ijpharm.2017.01.067

17. Truffi, M., Fiandra, L., Sorrentino, L., Monieri, M., Corsi, F., and Mazzucchelli, S., Pharmacol. Res., 2016, vol. 107 , p. 57.

https://doi.org/10.1016/j.phrs.2016.03.002

18. Andersson, J., Rosenholm, J., Areva, S., and Lindén, M., Chem. Mater., 2004, vol. 16, p. 4160.

https://doi.org/10.1021/cm0401490

19. Meng, H., Xue, M., Xia, T., Zhao, Y.-L., Tamanoi, F., Stoddart, J.F., Zink, J.I., and Nel, A.E., J. Am. Chem. Soc., 2010, vol. 132, p. 12690. https://doi.org/10.1021/ja104501a

20. Maciel, V.B.V., Yoshida, C.M.P., Pereira, S.M.S.S., Goycoolea, F.M., and Franco, T.T., Molecules, 2017, vol. 22, p. 1707. https://doi.org/10.3390/molecules22101707

21. Popat, A., Hartono, S.B., Stahr, F., Liu, J., Qiao, S.Z., and Lu, G.Q.(M.), Nanoscale, 2011, vol. 3, p. 2801. https://doi.org/10.1039/c1nr10224a

22. Engineering of Nanobiomaterials (Applications of Nanobiomaterials, vol. 2), Grumezescu, A.M., Amsterdam: Elsevier, 2016, vol. 2, p. 564.

23. Smistad, G., Jacobsen, J., and Sande, S.A., Int. J. Pharm., 2007, vol. 330, p. 14. https://doi.org/10.1016/j.ijpharm.2006.08.044

24. Dokka, S., Toledo, D., Shi, X., Castranova, V., and Rojanasakul, Y., Pharm. Res., 2000, vol. 17, p. 521. https://doi.org/10.1023/A:1007504613351

25. Dos Santos, N., Cox, K.A., McKenzie, C.A., van Baarda, F., Gallagher, R.C., Karlsson, G., Edwards, K., Mayer, L.D., Allen, C., and Bally, M.B., Biochim. 
Biophys. Acta, 2004, vol. 1661, p. 47.

https://doi.org/10.1016/j.bbamem.2003.11.016

26. Pattni, B.S., Chupin, V.V., and Torchilin, V.P., Chem. Rev., 2015, vol. 115, p. 10938.

https://doi.org/10.1021/acs.chemrev.5b00046

27. Toh, M.-R. and Chiu, G.N.C., Asian J. Pharm. Sci., 2013, vol. 8, p. 88.

https://doi.org/10.1016/j.ajps.2013.07.011

28. Shadyro, O.I., Yurkova, I.L., and Kisel, M.A., Int. J. Radiat. Biol., 2002, vol. 78, p. 211. https://doi.org/10.1080/09553000110104065

29. Mohammed, A.R., Bramwell, V.W., Coombes, A.G.A., and Perrie, Y., Methods, 2006, vol. 40, p. 30. https://doi.org/10.1016/j.ymeth.2006.05.025

30. Stark, B., Pabst, G., and Prassl, R., Eur. J. Pharm. Sci., 2010, vol. 41, p. 546. https://doi.org/10.1016/j.ejps.2010.08.010

31. Edwards, K.A. and Baeumner, A.J., Talanta, 2006, vol. 68, p. 1432. https://doi.org/10.1016/j.talanta.2005.08.031

32. Glavas-Dodov, M., Fredro-Kumbaradzi, E., Goracinova, K., Simonoska, M., Calis, S., Trajkovic-Jolevska, S., and Hincal, A.A., Int. J. Pharm., 2005, vol. 291, p. 79. https://doi.org/10.1016/j.ijpharm.2004.07.045

33. Ma, G., J. Controlled Release, 2014, vol. 193, p. 324. https://doi.org/10.1016/j.jconrel.2014.09.003

34. Chen, Y., Li, P., Modica, J.A., Drout, R.J., and Farha, O.K., J. Am. Chem. Soc., 2018, vol. 140, p. 5678. https://doi.org/10.1021/jacs.8b02089

35. Chen, T.-T., Yi, J.-T., Zhao, Y.-Y., and Chu, X., J. Am. Chem. Soc., 2018, vol. 140, p. 9912. https://doi.org/10.1021/jacs.8b04457

36. Peng, S., Liu, J., Qin, Y., Wang, H., Cao, B., Lu, L., and Yu, X., ACS Appl. Mater. Interfaces, 2019, vol. 11, p. 35604. https://doi.org/10.1021/acsami.9b15037

37. Mohammadi, A., Jafari, S.M., Mahoonak, A.S., and Ghorbani, M., Food Bioprocess Technol., 2021, vol. 14, p. 23. https://doi.org/10.1007/s11947-020-02513-X

38. Kumar, H., Kuča, K., Bhatia, S.K., Saini, K., Kaushal, A., Verma, R., Bhalla, T.C., and Kumar, D., Sensors, 2020, vol. 20, p. 1966. https://doi.org/10.3390/s20071966

39. Aisida, S.O., Akpa, P.A., Ahmad, I., Zhao, T.-k., Maaza, M., and Ezema, F.I., Eur. Polym. J., 2020, vol. 122, article no. 109371.

https://doi.org/10.1016/j.eurpolymj.2019.109371

40. Blackman, L.D., Varlas, S., Arno, M.C., Houston, Z.H., Fletcher, N.L., Thurecht, K.J., Hasan, M., Gibson, M.I., and O'Reilly, R.K., ACS Cent. Sci., 2018, vol. 4, p. 718. https://doi.org/10.1021/acscentsci.8b00168

41. Varlas, S., Foster, J.C., Georgiou, P.G., Keogh, R., Husband, J.T., Williams, D.S., and O'Reilly, R.K., Nanoscale, 2019, vol. 11, p. 12643. https://doi.org/10.1039/C9NR02507C
42. Cui, J., Ren, S., Sun, B., and Jia, S., Coord. Chem. Rev., 2018, vol. 370, p. 22. https://doi.org/10.1016/j.ccr.2018.05.004

43. Yoshimoto, M., Enzyme Stabilization and Immobilization: Methods and Protocols, Minteer, S.D., Ed., New York: Springer, 2017, p. 9.

https://doi.org/10.1007/978-1-4939-6499-4_2

44. Caruso, F., Trau, D., Möhwald, H., and Renneberg, R., Langmuir, 2000, vol. 16, p. 1485. https://doi.org/10.1021/la991161n

45. Chaize, B., Colletier, J.-P., Winterhalter, M., and Fournier, D., Artif. Cells, Blood Substitutes, Biotechnol., 2004, vol. 32, p. 67. https://doi.org/10.1081/BIO-120028669

46. Sakr, O.S. and Borchard, G., Biomacromolecules, 2013, vol. 14 , p. 2117. https://doi.org/10.1021/bm400198p

47. van Dongen, S.F.M., Nallani, M., Cornelissen, J.J.L.M., Nolte, R.J.M., and van Hest, J.C.M., Chem. Eur. J., 2009, vol. 15, p. 1107. https://doi.org/10.1002/chem.200802114

48. Le Meins, J.F., Sandre, O., and Lecommandoux, S., Eur. Phys. J. E: Soft Matter Biol. Phys., 2011, vol. 34, p. 14. https://doi.org/10.1140/epje/i2011-11014-y

49. Zyuzin, M.V., Ramos-Cabrer, P., and CarregalRomero, S., Immobilization of Enzymes and Cells: Methods and Protocols, Guisan, J.M., Bolivar, J.M., López-Gallego, F., and Rocha-Martín, J., Eds., New York: Springer. 2020, p. 227. https://doi.org/10.1007/978-1-0716-0215-7_15

50. Nobakht, N., Faramarzi, M.A., Shafiee, A., Khoobi, M., and Rafiee, E., Int. J. Biol. Macromol., 2018, vol. 113, p. 8. https://doi.org/10.1016/j.ijbiomac.2018.02.023

51. Gascón, V., Jiménez, M.B., Blanco, R.M., and SanchezSanchez, M., Catal. Today, 2018, vol. 304, p. 119. https://doi.org/10.1016/j.cattod.2017.10.022

52. Tadepalli, S., Yim, J., Cao, S., Wang, Z., Naik, R.R., and Singamaneni, S., Small, 2018, vol. 14, article no. 1702382 .

https://doi.org/10.1002/smll.201702382

53. Liang, K., Ricco, R., Doherty, C.M., Styles, M.J., Bell, S., Kirby, N., Mudie, S., Haylock, D., Hill, A.J., Doonan, C.J., and Falcaro, P., Nat. Commun., 2015, vol. 6, p. 7240. https://doi.org/10.1038/ncomms 8240

54. Knedel, T.-O., Ricklefs, E., Schlüsener, C., Urlacher, V.B., and Janiak, C., ChemistryOpen, 2019, vol. 8 , p. 1337. https://doi.org/10.1002/open.201900146

55. Wu, X., Yang, C., and Ge, J., Bioresour. Bioprocess., 2017, vol. 4, article no. 24. https://doi.org/10.1186/s40643-017-0154-8

56. Liang, W., Carraro, F., Solomon, M.B., Bell, S.G., Amenitsch, H., Sumby, C.J., White, N.G., Falcaro, P., and Doonan, C.J., J. Am. Chem. Soc., 2019, vol. 141, p. 14298 . https://doi.org/10.1021/jacs.9b06589 
57. Artem'ev, A.V. and Fedin, V.P., Russ. J. Org. Chem., 2019, vol. 55, p. 800.

https://doi.org/10.1134/S1070428019060101

58. Ganina, O.G., Bondarenko, G.N., Isaeva, V.I., Kustov, L.M., and Beletskaya, I.P., Russ. J. Org. Chem., 2019, vol. 55, p. 1813.

https://doi.org/10.1134/S1070428019120017

59. Hidalgo, T., Alonso-Nocelo, M., Bouzo, B.L., Reimondez-Troitiño, S., Abuin-Redondo, C., de la Fuente, M., and Horcajada, P., Nanoscale, 2020, vol. 12, p. 4839. https://doi.org/10.1039/C9NR08127E

60. Peng, S., Bie, B., Sun, Y., Liu, M., Cong, H., Zhou, W., Xia, Y., Tang, H., Deng, H., and Zhou, X., Nat. Commun., 2018, vol. 9, p. 1293. https://doi.org/10.1038/s41467-018-03650-w

61. Poddar, A., Joglekar, M., Hardikar, A., and Shukla, R., Progenitor Cells: Methods and Protocols, Joglekar, M.V. and Hardikar, A.A., Eds., New York: Humana Press, 2019, p. 81. https://doi.org/10.1007/978-1-4939-9631-5 7

62. Teplensky, M.H., Fantham, M., Poudel, C., Hockings, C., Lu, M., Guna, A., Aragones-Anglada, M., Moghadam, P.Z., Li, P., Farha, O.K., Bernaldo de Quirós Fernández, S., Richards, F.M., Jodrell, D.I., Kaminski Schierle, G., Kaminski, C.F., and Fairen-Jimenez, D., Chem, 2019, vol. 5, p. 2926.

https://doi.org/10.1016/j.chempr.2019.08.015

63. Poddar, A., Conesa, J.J., Liang, K., Dhakal, S., Reineck, P., Bryant, G., Pereiro, E., Ricco, R., Amenitsch, H., Doonan, C., Mulet, X., Doherty, C.M., Falcaro, P., and Shukla, R., Small, 2019, vol. 15, article no. 1902268 https://doi.org/10.1002/smll.201902268

64. Zhang, R., Teramura, Y., Fukazawa, K., and Ishihara, K., Macromol. Biosci., 2020, vol. 20, article no. 2000114. https://doi.org/10.1002/mabi.202000114

65. Lambert, C.R., Nijsure, D., Huynh, V., and Wylie, R.G., Biomed. Mater., 2018, vol. 13, article no. 045002. https://doi.org/10.1088/1748-605X/aab45d

66. Zhong, L., Feng, Y., Wang, G., Wang, Z., Bilal, M., Lv, H., Jia, S., and Cui, J., Int. J. Biol. Macromol., 2020, vol. 152 , p. 207. https://doi.org/10.1016/j.ijbiomac.2020.02.258

67. Zhuang, L.L., Li, M., and Ngo, H.H., Bioresour. Technol., 2020, vol. 308, article no. 123320. https://doi.org/10.1016/j.biortech.2020.123320

68. Zhou, Y., Chen, R., Yang, H., Bao, C., Fan, J., Wang, C., Lin, Q., and Zhu, L., J. Mater. Chem. B, 2020, vol. 8, p. 727 . https://doi.org/10.1039/c9tb02411e

69. Jafari, S., Maleki-Dizaji, N., Barar, J., BarzegarJalali, M., Rameshrad, M., and Adibkia, K., Eur. J. Pharm. Sci., 2016, vol. 91, p. 225. https://doi.org/10.1016/j.ejps.2016.05.014

70. Zhu, Z., Chen, Z., Luo, X., Liang, W., Li, S., He, J., Zhang, W., Hao, T., and Yang, Z., Chemosphere, 2020, vol. 240, article no. 124882 . https://doi.org/10.1016/j.chemosphere.2019.124882
71. Yu, L., Xia, K., Gong, C., Chen, J., Li, W., Zhao, Y., Guo, W., and Dai, H., Int. J. Biol. Macromol., 2020, vol. 160 , p. 101. https://doi.org/10.1016/j.ijbiomac.2020.05.161

72. Zhang, W., Wang, X.C., Li, X.Y., Zhang, L.L., and Jiang, F., Carbohydr. Polym., 2020, vol. 236, article no. 116043 .

https://doi.org/10.1016/j.carbpol.2020.116043

73. Yilmaz, E.N. and Zeugolis, D.I., Front. Bioeng. Biotechnol., 2020, vol. 8, p. 77. https://doi.org/10.3389/fbioe.2020.00077

74. Gur, S.D., Idil, N., and Aksoz, N., Appl. Biochem. Biotechnol., 2018, vol. 184, p. 538. https://doi.org/10.1007/s12010-017-2566-5

75. Wei, C., Zhou, Y., Zhuang, W., Li, G., Jiang, M., and Zhang, H., J. Biosci. Bioeng., 2018, vol. 125, p. 377. https://doi.org/10.1016/j.jbiosc.2017.09.011

76. Heim, S., Schnieder, I., Binz, D., Vogel, A., and Bilitewski, U., Biosens. Bioelectron., 1999, vol. 14, p. 187. https://doi.org/10.1016/S0956-5663(98)00118-3

77. Dubey, R.S. and Upadhyay, S.N., Biosens. Bioelectron., 2001, vol. 16, p. 995.

78. Galindo, E., Bautista, D., Garcia, J.L., and Quintero, R., Enzyme Microb. Technol., 1990, vol. 12, p. 642. https://doi.org/10.1016/0141-0229(90)90001-7

79. Hoshi, M., Sasamoto, Y., Nonaka, M., Toyama, K., and Watanabe, E., Biosens. Bioelectron., 1991, vol. 6, p. 15. https://doi.org/10.1016/0956-5663(91)85003-F

80. Karube, I., Suzuki, S., Okada, T., and Hikuma, M., Biochimie, 1980, vol. 62, p. 567. https://doi.org/10.1016/s0300-9084(80)80102-7

81. Kim, M.-N. and Kwon, H.-S., Biosens. Bioelectron., 1999, vol. 14, p. 1. https://doi.org/10.1016/S0956-5663(98)00107-9

82. Mulchandani, P., Lei, Y., Chen, W., Wang, J., and Mulchandani, A., Anal. Chim. Acta, 2002, vol. 470, p. 79. https://doi.org/10.1016/S0003-2670(02)00606-2

83. Renneberg, R., Riedel, K., Liebs, P., and Scheller, F., Anal. Lett., 1984, vol. 17, p. 349. https://doi.org/10.1080/00032718408069082

84. Riedel, K. and Scheller, F., Analyst, 1987, vol. 112, p. 341. https://doi.org/10.1039/AN9871200341

85. Katrlík, J., Brandšteter, R., Švorc, J., Rosenberg, M., and Miertuš, S., Anal. Chim. Acta, 1997, vol. 356, p. 217. https://doi.org/10.1016/S0003-2670(97)00524-2

86. Riedel, K., Renneberg, R., Wollenberger, U., Kaiser, G., and Scheller, F.W., J. Chem. Technol. Biotechnol., 1989, vol. 44 , p. 85. https://doi.org/10.1002/jctb.280440202

87. Rechnitz, G.A., Kobos, R.K., Riechel, S.J., and Gebauer, C.R., Anal. Chim. Acta, 1977, vol. 94, p. 357. https://doi.org/10.1016/S0003-2670(01)84537-2 
88. Matsunaga, T., Suzuki, T., and Tomoda, R., Enzyme Microb. Technol., 1984, vol. 6, p. 355. https://doi.org/10.1016/0141-0229(84)90048-6

89. Bilal, M., Adeel, M., Rasheed, T., and Iqbal, H.M.N., J. Mater. Res. Technol., 2019, vol. 8, p. 2359. https://doi.org/10.1016/j.jmrt.2018.12.001

90. Racek, J., Appl. Microbiol. Biotechnol., 1991, vol. 34, p. 473. https://doi.org/10.1007/BF00180573

91. Fedorov, A.Yu., Volchenko, E.V., Singirtsev, I.N., Korzhenevich, V.I., and Shub, G.M., Prikl. Biokhim. Mikrobiol., 1999, vol. 35, p. 165.

92. Garcia, J.L., Nunez, C.J., Gonzalez, E.G., Osuna, J., Soberon, X., and Galindo, E., Appl. Biochem. Biotechnol., 1998, vol. 73, p. 243.

https://doi.org/10.1007/BF02785659

93. Gonchar, M.V., Maidan, M.M., Moroz, O.M., Woodward, J.R., and Sibirny, A.A., Biosens. Bioelectron., 1998, vol. 13, p. 945.

https://doi.org/10.1016/s0956-5663(98)00034-7

94. Schmidt, A., Standfuss-Gabisch, C., and Bilitewski, U., Biosens. Bioelectron., 1996, vol. 11, p. 1139. https://doi.org/10.1016/0956-5663(96)82336-0

95. Jung, S.W., Byun, J.H., Oh, S.H., Kim, T.H., Park, J.S., Rho, G.J., and Lee, J.H., Carbohydr. Polym., 2018, vol. 180 , p. 216. https://doi.org/10.1016/j.carbpol.2017.10.029

96. Held, M., Schuhmann, W., Jahreis, K., and Schmidt, H.L., Biosens. Bioelectron., 2002, vol. 17, p. 1089. https://doi.org/10.1016/s0956-5663(02)00103-3

97. Svitel, J., Curilla, O., and Tkac, J., Biotechnol. Appl. Biochem., 1998, vol. 27, p. 153.

98. Karube, I., Mitsuda, S., and Suzuki, S., Eur. J. Appl. Microbiol. Biotechnol., 1979, vol. 7, p. 343.

99. Timur, S., Seta, L.D., Pazarlioglu, N., Pilloton, R., and Telefoncu, A., Process Biochem., 2004, vol. 39, p. 1325. https://doi.org/10.1016/S0032-9592(03)00265-6

100. Horsburgh, A.M., Mardlin, D.P., Turner, N.L., Henkler, R., Strachan, N., Glover, L.A., Paton, G.I., and Killham, K., Biosens. Bioelectron., 2002, vol. 17, p. 495. https://doi.org/10.1016/S0956-5663(01)00321-9

101. Riedel, K., Beyersdorf-Radeck, B., Neumann, B., and Schaller, F., Appl. Microbiol. Biotechnol., 1995, vol. 43 , p. 7.

https://doi.org/10.1007/BF00170614

102. Anderson, D.E.J., Truong, K.P., Hagen, M.W., Yim, E.K.F., and Hinds, M.T., Acta Biomater., 2019, vol. 86, p. 291. https://doi.org/10.1016/j.actbio.2019.01.008

103. Wollenberger, U., Scheller, F., and Atrat, P., Anal. Lett., 1980, vol. 13, p. 1201.

https://doi.org/10.1080/00032718008055725
104. Philp, J.C., Balmand, S., Hajto, E., Bailey, M.J., Wiles, S., Whiteley, A.S., Lilley, A.K., Hajto, J., and Dunbar, S.A., Anal. Chim. Acta, 2003, vol. 487, p. 61. https://doi.org/10.1016/S0003-2670(03)00358-1

105. Simonian, A.L., Rainina, E.I., Lozinsky, V.I., Badalian, I.E., Khachatrian, G.E., Tatikian, S., Makhlis, T.A., and Varfolomeyev, S.D., Appl. Biochem. Biotechnol., 1992, vol. 36, p. 199. https://doi.org/10.1007/BF02921779

106. Fukui, S. and Tanaka, A., Adv. Biochem. Eng. Biotechnol. 1984, vol. 29, p. 1. https://doi.org/10.1007/Bfb0000689

107. Grinyte, R., Barroso, J., Moller, M., Saa, L., and Pavlov, V., ACS Appl. Mater. Interfaces, 2016, vol. 8, p. 29252. https://doi.org/10.1021/acsami.6b08362

108. Odaci, D., Timur, S., and Telefoncu, A., Sens. Actuators, B, 2008, vol. 134, p. 89. https://doi.org/10.1016/j.snb.2008.04.013

109. Yao, Y., Yang, L., Feng, L.F., Yue, Z.W., Zhao, N.H., Li, Z., and He, Z.X., Stem Cell Res. Ther., 2020, vol. 11, p. 136. https://doi.org/10.1186/s13287-020-01637-3

110. Shahzadi, L., Yar, M., Jamal, A., Siddiqi, S.A., Chaudhry, A.A., Zahid, S., Tariq, M., Rehman, I.U., and MacNeil, S., J. Biomater. Appl., 2016, vol. 31, p. 582. https://doi.org/10.1177/0885328216650125

111. Chan, C., Lehmann, M., Tag, K., Lung, M., Kunze, G., Riedel, K., Gruendig, B., and Renneberg, R., Biosens. Bioelectron., 1999, vol. 14, p. 131. https://doi.org/10.1016/s0956-5663(98)00110-9

112. Gaberlein, S., Spener, F., and Zaborosch, C., Appl. Microbiol. Biotechnol., 2000, vol. 54, p. 652. https://doi.org/10.1007/s002530000437

113. König, A., Riedel, K., and Metzger, J.W., Biosens. Bioelectron., 1998, vol. 13, p. 869. https://doi.org/10.1016/S0956-5663(98)00054-2

114. König, A., Zaborosch, C., Muscat, A., Vorlop, K.-D., and Spener, F., Appl. Microbiol. Biotechnol., 1996, vol. 45 , p. 844 . https://doi.org/10.1007/s002530050772

115. Faust, H.J., Sommerfeld, S.D., Rathod, S., Rittenbach, A., Ray Banerjee, S., Tsui, B.M.W., Pomper, M., Amzel, M.L., Singh, A., and Elisseeff, J.H., Biomaterials, 2018, vol. 183, p. 93. https://doi.org/10.1016/j.biomaterials.2018.08.045

116. Smirnova, D.V., Rubtsova, M.Y., Grigorenko, V.G., and Ugarova, N.N., Photochem. Photobiol., 2017, vol. 93 , p. 541. https://doi.org/10.1111/php.12666

117. Tham, D.K.L. and Moukhles, H., J. Vis. Exp., 2017, vol. 125, article ID e55974. https://doi.org/10.3791/55974 
118. Ikonomova, S.P., Le, M.T., Kalla, N., and Karlsson, A.J., Biotechnol. Appl. Biochem., 2018, vol. 65 , p. 580 .

https://doi.org/10.1002/bab.1645

119. Chen, D., Cao, Y., Liu, B., and Kong, J., Anal. Bioanal. Chem., 2002, vol. 372, p. 737.

https://doi.org/10.1007/s00216-001-1214-6

120. Jia, J., Tang, M., Chen, X., Qi, L., and Dong, S., Biosens. Bioelectron., 2003, vol. 18, p. 1023. https://doi.org/10.1016/S0956-5663(02)00225-7

121. Tetteh, G., Khan, A.S., Delaine-Smith, R.M., Reilly, G.C., and Rehman, I.U., J. Mech. Behav. Biomed. Mater., 2014, vol. 39, p. 95.

https://doi.org/10.1016/j.jmbbm.2014.06.019

122. Kaiser, P., Reich, S., Leykam, D., Willert-Porada, M., Greiner, A., and Freitag, R., Macromol. Biosci., 2017, vol. 17 , article no. 1600442 .

https://doi.org/10.1002/mabi.201600442

123. Magyari, K., Nagy-Simon, T., Vulpoi, A., Popescu, R.A., Licarete, E., Stefan, R., Hernadi, K., Papuc, I., and Baia, L., Mater. Sci. Eng., C, 2017, vol. 76, p. 752. https://doi.org/10.1016/j.msec.2017.03.138

124. Jha, S.K., Kanungo, M., Nath, A., and D'Souza, S.F., Biosens. Bioelectron., 2009, vol. 24, p. 2637. https://doi.org/10.1016/j.bios.2009.01.024

125. Strehlitz, B. and Bohland, C., Fourth Workshop on Biosensors and Biological Techniques in Environmental Analysis, Spain, Menorca, 1999, O16.

126. Quijada, C., Leite-Rosa, L., Berenguer, R., and BouBelda, E., Materials, 2019, vol. 12, p. 2516. https://doi.org/10.3390/ma12162516

127. Shaikh, M.O., Srikanth, B., Zhu, P.Y., and Chuang, C.H., Sensors, 2019, vol. 19, p. 3990. https://doi.org/10.3390/s19183990

128. El-Maiss, J., Cuccarese, M., Maerten, C., Lupattelli, P., Chiummiento, L., Funicello, M., Schaaf, P., Jierry, L., and Boulmedais, F., ACS Appl. Mater. Interfaces, 2018, vol. 10 , p. 18574.

https://doi.org/10.1021/acsami.8b04764

129. Trzaskowska, P.A., Kuzminska, A., ButrukRaszeja, B., Rybak, E., and Ciach, T., Colloids Surf., B, 2018, vol. 167, p. 499.

https://doi.org/10.1016/j.colsurfb.2018.04.052

130. Deng, L., Guo, S., Zhou, M., Liu, L., Liu, C., and Dong, S., Biosens. Bioelectron., 2010, vol. 25, p. 2189. https://doi.org/10.1016/j.bios.2010.02.005

131. Gorityala, B.K., Ma, J., Wang, X., Chen, P., and Liu, X.W., Chem. Soc. Rev., 2010, vol. 39, p. 2925. https://doi.org/10.1039/b919525b

132. Hiep, H.M., Endo, T., Kim, D.K., and Tamiya, E., Nanomaterials Synthesis, Interfacing, and Integrating in Devices, Circuits, and Systems II, Boston, MA, 2007, no. 67680I.
133. Hnaien, M., Lagarde, F., Bausells, J., Errachid, A., and Jaffrezic-Renault, N., Anal. Bioanal. Chem., 2010, vol. 400, p. 1083. https://doi.org/10.1007/s00216-010-4336-X

134. Huang, Y., Palkar, P.V., Li, L.J., Zhang, H., and Chen, P., Biosens. Bioelectron., 2010, vol. 25, p. 1834. https://doi.org/10.1016/j.bios.2009.12.011

135. Zhu, Y.C., Li, Z., Liu, X.N., Fan, G.C., Han, D.M., Zhang, P.K., Zhao, W.W., Xu, J.J., and Chen, H.Y., Biosens. Bioelectron., 2020, vol. 148, article no. 111836. https://doi.org/10.1016/j.bios.2019.111836

136. Yoon, J., Shin, M., Lee, T., and Choi, J.W., Materials, 2020, vol. 13, p. 299. https://doi.org/10.3390/ma13020299

137. Wang, H., Jiang, Y., Zhang, Y., Zhang, Z., Yang, X., Ali, M.A., Fox, E.M., Gobius, K.S., and Man, C., J. Dairy Sci., 2018, vol. 101, p. 10775. https://doi.org/10.3168/jds.2018-15258

138. Liang, K., Richardson, J.J., Cui, J., Caruso, F., Doonan, C.J., and Falcaro, P., Adv. Mater., 2016, vol. 28 , p. 7910. https://doi.org/10.1002/adma.201602335

139. Liang, K., Richardson, J.J., Doonan, C.J., Mulet, X., Ju, Y., Cui, J., Caruso, F., and Falcaro, P., Angew. Chem., Int. Ed., 2017, vol. 56, p. 8510. https://doi.org/10.1002/anie.201704120

140. Ji, Z., Zhang, H., Liu, H., Yaghi, O.M., and Yang, P., Proc. Natl. Acad. Sci. U. S. A., 2018, vol. 115, p. 10582. https://doi.org/10.1073/pnas.1808829115

141. Deng, Q., Sun, P., Zhang, L., Liu, Z., Wang, H., Ren, J., and Qu, X., Adv. Funct. Mater., 2019, vol. 29, article no. 1903018. https://doi.org/10.1002/adfm.201903018

142. Luzuriaga, M.A., Welch, R.P., Dharmarwardana, M., Benjamin, C.E., Li, S., Shahrivarkevishahi, A., Popal, S., Tuong, L.H., Creswell, C.T., and Gassensmith, J.J., ACS Appl. Mater. Interfaces, 2019, vol. 11, p. 9740 . https://doi.org/10.1021/acsami.8b20504

143. Zhang, Y., Wang, F., Ju, E., Liu, Z., Chen, Z., Ren, J., and Qu, X., Adv. Funct. Mater., 2016, vol. 26, p. 6454. https://doi.org/10.1002/adfm.201600650

144. Zhong, X., Zhang, Y., Tan, L., Zheng, T., Hou, Y., Hong, X., Du, G., Chen, X., Zhang, Y., and Sun, X., J. Controlled Release, 2019, vol. 300, p. 81. https://doi.org/10.1016/j.jconrel.2019.02.035

145. Li, W., Zhang, Y., Xu, Z., Meng, Q., Fan, Z., Ye, S., and Zhang, G., Angew. Chem., Int. Ed., 2016, vol. 55, p. 955 . https://doi.org/10.1002/anie.201508795

146. Cho, M.O., Yoon, S., and Kim, J.K., Proc. 1st Global Congr. on NanoEngineering for Medicine and Biology: Advancing Health Care through NanoEngineering and Computing (NEMB 2010), Houston, TX. 2010, p. 335. 
147. Sakurai, K., Teramura, Y., and Iwata, H., Biomaterials, 2011, vol. 32, p. 3596.

https://doi.org/10.1016/j.biomaterials.2011.01.066

148. Cho, H., Parameswaran, M., and Yu, H.-Z., Sens. Actuators, B, 2007, vol. 123, p. 749. https://doi.org/10.1016/j.snb.2006.10.022

149. Cook, C.C., Wang, T., and Derby, B., Chem. Commun., 2010, vol. 46, p. 5452. https://doi.org/10.1039/c0cc00567c

150. Kwok, C.Y., Proc. Int. Conf. on Knowledge-Based Intelligent Electronic Systems, KES, 1998, vol. 3, p. 442.

151. Lin, L. and He, W., Digital Fabrication 2006, Denver, CO, 2006, p. 98

152. Choi, I., Yang, Y.I., Kim, Y.-J., Kim, Y., Hahn, J.-S., Choi, K., and Yi, J., Langmuir, 2008, vol. 24, p. 2597. https://doi.org/10.1021/la701679a

153. Wang, Q., Zhang, X., Huang, L., Zhang, Z., and Dong, S., Angew. Chem., Int. Ed., 2017, vol. 56, p. 16082. https://doi.org/10.1002/anie.201710418

154. Ricco, R., Wied, P., Nidetzky, B., Amenitsch, H., and Falcaro, P., Chem, Commun., 2020, vol. 56, p. 5775. https://doi.org/10.1039/C9CC09358C

155. Lian, X., Ph.D. Thesis, 2018.

156. Ahmad, R., Shanahan, J., Rizaldo, S., Kissel, D.S., and Stone, K.L., Catalysts, 2020, vol. 10, p. 499. https://doi.org/10.3390/catal10050499

157. Li, Y., Wen, L., Tan, T., and Lv, Y., Front. Bioeng. Biotechnol., 2019, vol. 7, p. 394. https://doi.org/10.3389/fbioe.2019.00394

158. Nath, I., Chakraborty, J., and Verpoort, F., Chem. Soc. Rev., 2016, vol. 45, p. 4127. https://doi.org/10.1039/C6CS00047A

159. Wang, J., Li, W., and Zheng, Y.-Q., Analyst, 2019, vol. 144, p. 6041. https://doi.org/10.1039/C9AN00813F

160. Yang, H., Yang, R., Zhang, P., Qin, Y., Chen, T., and Ye, F., Microchim. Acta, 2017, vol. 184, p. 4629. https://doi.org/10.1007/s00604-017-2509-4

161. He, J., Zhang, Y., Zhang, X., and Huang, Y., Sci. Rep., 2018, vol. 8, p. 5159. https://doi.org/10.1038/s41598-018-23557-2

162. Liang, H., Lin, F., Zhang, Z., Liu, B., Jiang, S., Yuan, Q., and Liu, J., ACS Appl. Mater. Interfaces, 2017, vol. 9, p. 1352. https://doi.org/10.1021/acsami.6b15124

163. Wang, H., Chen, Y., Wang, H., Liu, X., Zhou, X., and Wang, F., Angew. Chem., Int. Ed., 2019, vol. 58, p. 7380 .

https://doi.org/10.1002/anie.201902714

164. Hamedi, A., Caldera, F., Trotta, F., Borhani Zarandi, M., Rubin Pedrazzo, A., and Cecone, C., Acta Sci. Pharm. Sci., 2019, vol. 3, no. 4, p. 107. https://doi.org/10.13140/RG.2.2.24033.97125
165. Kan, P., Tsao, C.W., Wang, A.J., Su, W.C., and Liang, H.F., J. Drug Delivery, 2011, vol. 2011, article ID 629234. https://doi.org/10.1155/2011/629234

166. Katsai, O. and Ruban, O., Int. J. Appl. Pharm., 2019, vol. 11, p. 418. https://doi.org/10.22159/ijap.2019v11i4.32080

167. Rideau, E., Dimova, R., Schwille, P., Wurm, F.R., and Landfester, K., Chem. Soc. Rev., 2018, vol. 47, p. 8572. https://doi.org/10.1039/c8cs00162f

168. Zaborova, O.V., Cand. Sci. (Chem.) Dissertation, Moscow, 2014.

169. Sharma, A. and Sharma, U.S., Int. J. Pharm., 1997, vol. 154, p. 123. https://doi.org/10.1016/S0378-5173(97)00135-X

170. Bioceramics and Biocomposites. From Research to Clinical Practice, Antoniac, I., Ed., Hoboken, NJ: Wiley, 2019, p. 385.

171. Mishra, M.K., Singh, T.K., and Tiwari, P., Adv. J. Pharm. Life Sci. Res., 2016, vol. 4, p. 41.

172. Blume, G. and Cevc, G., Biochim. Biophys. Acta, Biomembr., 1993, vol. 1146, p. 157. https://doi.org/10.1016/0005-2736(93)90351-Y

173. Antimisiaris, S.G., Kallinteri, P., and Fatouros, D.G., Pharmaceutical Sciences Encyclopedia: Drug Discovery, Development, and Manufacturing, 2010. https://doi.org/10.1002/9780470571224.pse352

174. Kim, S., Shi, Y., Kim, J.Y., Park, K., and Cheng, J.X., Expert Opin. Drug Delivery, 2010, vol. 7, p. 49. https://doi.org/10.1517/17425240903380446

175. Yang, R., Zhang, S., Kong, D., Gao, X., Zhao, Y., and Wang, Z., Pharm. Res., 2012, vol. 29, p. 3512. https://doi.org/10.1007/s11095-012-0848-8

176. Letchford, K. and Burt, H., Eur. J. Pharm. Biopharm., 2007, vol. 65 , p. 259. https://doi.org/10.1016/j.ejpb.2006.11.009

177. Heffernan, M.J. and Murthy, N., Ann. Biomed. Eng., 2009, vol. 37, p. 1993. https://doi.org/10.1007/s10439-009-9734-x

178. Mao, A.S., Shin, J.W., Utech, S., Wang, H., Uzun, O., Li, W., Cooper, M., Hu, Y., Zhang, L., Weitz, D.A., and Mooney, D.J., Nat. Mater., 2017, vol. 16, p. 236. https://doi.org/10.1038/nmat4781

179. Chen, Y., Zheng, X., Qian, H., Mao, Z., Ding, D., and Jiang, X., ACS Appl. Mater. Interfaces, 2010, vol. 2, p. 3532. https://oi.org/10.1021/am100709d

180. Li, Z., Barnes, J.C., Bosoy, A., Stoddart, J.F., and Zink, J.I., Chem. Soc. Rev., 2012, vol. 41, p. 2590. https://doi.org/10.1039/c1cs15246g

181. Biopolymer Nanostructures for Food Encapsulation Purposes, Jafari, S.M., Ed., London: Academic, 2019, vol. 1. https://doi.org/10.1016/C2017-0-03166-X

182. Muñoz, B., Rámila, A., Pérez-Pariente, J., Díaz, I., and Vallet-Regí, M., Chem. Mater., 2003, vol. 15, p. 500. https://doi.org/10.1021/cm021217q 
183. Fundamental Biomaterials. Ceramics, Thomas, S., Balakrishnan, P., and Sreekala, M.S., Eds., Duxford: Woodhead Publishing, 2018.

184. Lu, F., Wu, S.H., Hung, Y., and Mou, C.Y., Small, 2009, vol. 5, p. 1408. https://doi.org/10.1002/smll.200900005

185. Chung, T.-H., Wu, S.-H., Yao, M., Lu, C.-W., Lin, Y.-S., Hung, Y., Mou, C.-Y., Chen, Y.-C., and Huang, D.-M., Biomaterials, 2007, vol. 28, p. 2959. https://doi.org/10.1016/j.biomaterials.2007.03.006

186. Slowing, I.I., Vivero-Escoto, J.L., Wu, C.W., and Lin, V.S., Adv. Drug Delivery Rev., 2008, vol. 60, p. 1278. https://doi.org/10.1016/j.addr.2008.03.012
187. Lin, F.-Y., Cheng, C.-Y., Chuang, Y.-H., and Tung, S.-H., Polymer, 2018, vol. 134, p. 117. https://doi.org/10.1016/j.polymer.2017.11.060

188. Das, S., Sharma, D.K., Chakrabarty, S., Chowdhury, A., and Sen Gupta, S., Langmuir, 2015, vol. 31, p. 3402 .

https://doi.org/10.1021/la503993e

189. Dionzou, M., Morere, A., Roux, C., Lonetti, B., Marty, J.D., Mingotaud, C., Joseph, P., Goudouneche, D., Payre, B., Leonetti, M., and Mingotaud, A.F., Soft Matter, 2016, vol. 12, p. 2166. https://doi.org/10.1039/c5sm01863c 